Tanjungpura Law Journal, Vol. 4, Issue 2, July 2020: 191 - 205

ISSN Print: 2541-0482 | ISSN Online: 2541-0490

Open Access at: http://jurnal.untan.ac.id/index.php/tlj

Article Info

Submitted: 15 Februari 2020 | Reviewed: 13 Mei 2020 | Accepted: 30 Juni 2020

\title{
PELAKSANAAN KEWAJIBAN NEGARA DALAM PEMENUHAN HAK ATAS PENDIDIKAN DASAR BERDASARKAN INTERNATIONAL COVENANT ON ECONOMIC, SOCIAL AND CULTURAL RIGHTS (STUDI DI KOTA SINGKAWANG)
}

\author{
Endah Rantau Itasari ${ }^{1}$
}

\begin{abstract}
Indonesia as a party to the International Covenant on Economic, Social, and Cultural Rights (ICESCR) is bound to implement these provisions based on the international obligations contained therein, including concerning the fulfillment of the right to basic education. This paper is the result of research on how the implementation of the obligation to fulfill the right to basic education, especially in Singkawang City, is based on the ICESC. This research is empirical normative legal research using primary data and secondary data. The data obtained through interviews and library research were then analyzed qualitatively. From the research results, it was found that the implementation of the fulfillment of the right to basic education based on the ICESCR in Singkawang City has been gradually fulfilled. Technical factors, geographical factors, and factors implementing the provisions of laws and regulations that are not yet synchronized and complete are the determining factors for the fulfillment of basic education rights in Singkawang City.
\end{abstract}

Keywords: ICESCR; right to basic education; state responsibility

\begin{abstract}
Abstrak
Indonesia sebagai pihak pada International Covenant on Economic, Social and Cultural Rights (ICESCR) terikat untuk melaksanakan ketentuan-ketentuan tersebut berdasarkan kewajiban-kewajiban internasional yang terkandung di dalamnya, termasuk dalam kaitannya dengan pemenuhan hak atas pendidikan dasar. Tulisan ini merupakan hasil penelitian terhadap bagaimana pelaksanaan kewajiban pemenuhan hak atas pendidikan dasar, khususnya di Kota Singkawang berdasarkan ICESC. Penelitian ini adalah penelitian hukum normatif empiris dengan menggunakan data primer dan data sekunder. Data yang diperoleh melalui wawancara dan melalui penelitian kepustakaan tersebut selanjutnya dianalisis secara kualitatif. Dari hasil penelitian didapatkan hasil bahwa pelaksanaan pemenuhan hak atas pendidikan dasar berdasarkan ICESCR di Kota Singkawang telah secara bertahap dipenuhi. Faktor teknis, faktor geografis dan faktor implementasi ketentuan peraturan perundangan-undangan yang belum sinkron dan komplit menjadi faktor-faktor penentu pemenuhan hak pendidikan dasar di Kota Singkawang.
\end{abstract}

Kata Kunci: hak atas pendidikan dasar; ICESCR; kewajiban negara

${ }^{1}$ Fakultas Hukum Universitas Tanjungpura, email: itafira@yahoo.com 


\section{PENDAHULUAN}

Eksistensi hak atas pendidikan sudah tidak diragukan lagi keberadaannya baik di tingkat nasional maupun internasional ${ }^{2}$. Khusus di Indonesia, dinamika politik hukum nasional mempengaruhi pelaksanaan hak atas pendidikan yang berasal dari ketentuan-ketentuan pokok hukum hak asasi manusia internasional seperti dalam The Universal Declaration on Human Rights (UDHR)1949, The International Convention on Economic, Social and Cultural Rights (ICESCR)1966 dan dalam The Convention on The Rights of The Child 1989. Indonesia telah meratifikasi ICESCR tersebut pada tanggal 30 September 2005 melalui Undang-Undang Nomor 11 Tahun 2005 tentang Pengesahan The International Covenant on Economic, Social and Cultural Rights ${ }^{3}$.

Hakekat hak atas pendidikan pada tingkat pendidikan dasar, sebagaimana ditegaskan dalam ICESCR, merupakan suatu kondisi tertentu harus diciptakan oleh negara peratifikasi ${ }^{4}$. Aspek substansi pendidikan dan manajerial

2 Klaus Dieter Beiter, 2005, The Protection of the Right to Education by International Law, Martinus Nijhoff Publisher, hIm. 1-10.

3 Kovenan Internasional tentang Hak-Hak Ekonomi, Sosial dan Budaya) yang termuat dalam Lembaran Negara Republik Indonesia Tahun 2005 Nomor 118, Tambahan Lembaran Negara Republik Indonesia Nomor 4557.

${ }^{4}$ M. Freeman, 1992, "The Limits of Children's Rights, dalam The Ideologies of Children's Rights, hlm. 30-31. penyelenggaraan pendidikan merupakan elemen dasar dalam Pasal 13 ICESCR bagi negara untuk menyediakan pendidikan dasar bagi setiap orang. Aspek ketersediaan dan kemudahan sarana dan prasarana pendidikan, dan aspek penerimaan dan daya penyesuaian merupakan segmen-segmen hukum (indikator) yang harus dikondisikan pemenuhannya secara bertahap oleh negara untuk setiap saat dicapai dan ditingkatkan pemenuhannya dalam bidang pendidikan, khususnya pendidikan dasar dan menengah ${ }^{5}$.

Indonesia sebagai pihak pada ICESCR terikat untuk melaksanakan ketentuan-ketentuan tersebut berdasarkan kewajiban-kewajiban internasional yang terkandung di dalamnya $^{6}$. Bonanza Perwira Taihitu memberikan kerangka argumentatif bahwa politik hukum nasional Indonesia terhadap pelaksanaan ketentuan-ketentuan hukum hak asasi manusia internasional tersebut di atas antara tahun 1990 sampai dengan akhir tahun 2005 lebih cenderung bersifat sebagai sebuah pencitraan nasional di forum internasional ${ }^{7}$. Dengan demikian,

\footnotetext{
${ }^{5}$ Katarina Tomasevski, "Indicators" dalam Asbjorn Eide, Catarina Krause, Allan Rosas, 1995, Economic, Social and Cultural Rights, $A$ Textbook, Martinus Nijhoff, Dordrecht, hlm. 390.

${ }^{6}$ M Santos Pais, "A Human Rights Conceptual Framework for Children's Rights" dalam UNICEF Innovative Essay No.9, hlm. 5.

7 Bonanza Perwira Taihitu, 2003, "Penaatan
} 
kewajiban-kewajiban dasar dalam ketentuan tersebut dilaksanakan untuk lebih menarik simpati luar negeri dari pada pemanfaatannya untuk kepentingan nasional ${ }^{8}$.

Untuk memastikan pemenuhan kebutuhan masyarakat akan pendidikan yang layak, negara mempunyai kewajiban untuk memastikan penyediaan sistem pendidikan dan kurikulum yang memadai, penyediaan beasiswa, penyediaan sarana dan prasarana yang memadai, meningkatkan kualitas tenaga pendidik baik guru maupun dosen di perguruan tinggi ${ }^{9}$. Menurut kewajiban yang terkandung dalam ICESCR, sistem pendidikan yang ditetapkan oleh pemerintah harus dapat menjangkau semua warganegara, dapat diakses secara bebas tanpa diskriminasi dan secara ekonomi dan psikologis dapat diterima, serta sifatnya dapat menyesuaikan diri dengan perkembangan zaman ${ }^{10}$.

Putusan Mahkamah Konstitusi dalam Perkara Nomor 012/PUU-III/2005 Mengenai Pengujian UU No. 36 Tahun 2004 Tentang APBN terhadap

Indonesia Pada Standar-Standar Hak Asasi Manusia Internasional', Tesis Fakultas IImu Sosial dan IImu Politik Universitas Indonesia, hlm. 134-135.

$8 \mathrm{lbid}, \mathrm{hlm} .105$.

${ }^{9}$ Committee on Economic, Social and Cultural Rights General Comment 13, The Right to Education (Art. 13), 08/12/99, E/C.12/1999/10, CESCR, 8 December 1999.

${ }^{10}$ Colin Wringe, 2006, Moral Education: Beyond the Teaching Rights and Wrong, Springer, hlm. 51-52.

193 pengakuan, pemajuan dan perlindungan hak asasi manusia dalam bidang pendidikan mempertegas perdebatan lama yang tidak kunjung akhir mengenai kewajiban negara terhadap pemenuhan hak ekonomi, sosial dan budaya seperti yang termaktub dalam Kovenan. ${ }^{11}$

Di Provinsi Kalimantan Barat, kendala geografis dengan disparitas dan kontur alam berupa hutan dan perbukitan menyebabkan akses terhadap pendidikan menjadi kurang sehingga keterjangkauan menjadi rendah. Meskipun di beberapa level nampak terlihat adanya upaya-upaya Pemerintah Pusat dan Pemerintah Daerah Provinsi Kalbar untuk menangani persoalan-persoalan tersebut, namun demikian langkah-langkah penanganan tersebut masih belum fokus baik dalam aspek kualitas dan kuantitas sarana dan prasarana $^{12}$. Selain itu, dinamika politik lokal dengan dilaksanakannya kebijakan desentralisasi yang berupa pelimpahan kewenangan penyelenggaraan pendidikan dari Pemerintah Pusat ke Pemda sebagai jawaban pemerataan dan efektivitas pelaksanaan pendidikan juga tidak dengan sendirinya membuat pemenuhan hak atas pendidikan dasar. Sebaliknya, pelimpahan kewenangan ini justru berakibat pada pemunduran

\footnotetext{
11 Heribertus Jaka Triyana, "Implikasi Hukum Ratifikasi Kovenan Hak Ekonomi Sosial dan Budaya Terhadap Pemenuhan Hak Atas Pendidikan di Indonesia", Jurnal Hukum dan HAM, Vol. 4 Nomor 1 (Juni 2006), hlm. 27-30.

12 Ibid.
} 
kualitas pendidikan sebab tidak semua pemerintahan daerah kabupaten memiliki kemampuan yang sama, baik dari sisi kapasitas personel dan anggaran yang merata ${ }^{13}$.

Dengan telah diratifikasinya ICESCR membuat Indonesia terikat pada kewajiban-kewajiban internasional yang ditentukan dalam ICESCR tersebut untuk menghormati dan memenuhi hak-hak ekonomi, sosial dan budaya termasuk juga hak atas pendidikan bagi setiap warga negaranya ${ }^{14}$. Kondisi ini sedikit banyak akan berpengaruh terhadap pelaksanaan kewajiban negara untuk memenuhi hak atas pendidikan bagi warga negaranya sehingga kajian pemenuhan hak atas pendidikan dasar di Provinsi Kalbar.

Kota Singkawang sebagai kota terbesar kedua di Kalimantan Barat menjadi lokasi yang menarik untuk mengetahui bagaimana pelaksanaan kewajiban pemenuhan hak atas pendidikan dasar. Kota Singkawang secara geografis berdekatan dengan dua kabupaten yang berbatasan dengan wilayah Malaysia, yaitu: Kabupaten Sambas dan Kabupaten Bengkayang, sementara wilayah perbatasan menjadi temuan sebagai "wilayah tak berkeinginan untuk sekolah". 15 "Wilayah

\footnotetext{
13 Ibid.

14 Ibid.

15 Biro Hukum dan Organisasi Setjen Kemendikbud, 2011, "Monitoring dan Evaluasi Pemenuhan Hak Atas Pendidikan di Indonesia
}

tak berkeinginan sekolah" muncul di wilayah tersebut karena beberapa faktor khusus. Faktor tersebut adalah: (1). minimnya sarana dan prasarana, (2). kecemburuan akibat perbedaan fasilitas dengan negara tetangga yang langsung terlihat, (3). faktor geografis, keengganan pelaku pendidikan melaksanakan tugas dan fungsi pendidik, dan (4). rendahnya alokasi dana pendidikan telah menyebabkan ketertinggalan dan ketimpangan memperoleh akses pendidikan di wilayah-wilayah perbatasan tersebut. ${ }^{16}$

Selain itu, Kota Singkawang memiliki wilayah yang luas dengan karakteristik wilayah perkotaan pada daerah pusat-pusat perdagangan dan pemerintahan dan masih memiliki wilayah dengan karakteristik pedesaan pada sebagian besar wilayah lainnya. Kondisi tersebut di atas yang mendorong kajian untuk mengetahui bagaimana pelaksanaan kewajiban pemenuhan hak atas pendidikan dasar di Kota Singkawang.

\section{Metode}

Penelitian ini adalah penelitian hukum normatif empiris untuk memperoleh keunggulan dan kebenaran akademik terhadap pemenuhan

Tahun 2011", Kemdikbud, hlm. 25-30.

${ }^{16}$ Marzuki, "Permasalahan Pemenuhan Hak Atas Pendidikan di Wilayah Provinsi Kalimantan Barat", Makalah Forum Grup Discussion, Pemetaan Permasalahan Pendidikan Di Wilayah Perbatasan Negara, Setjen Kemdikbud, Hotel Park Jakarta, 23-24 November 2011. 
kewajiban internasional HAM yang diterima Indonesia, khususnya di bidang pendidikan berdasarkan ketentuan ICESCR. ${ }^{17}$

Penelitian ini menggunakan data yang diperoleh langsung dari responden dan narasumber (data primer) dan data sekunder. ${ }^{18}$ Data primer dalam penelitian ini diperoleh melalui wawancara melalui instrumen pedoman wawancara, sedangkan data sekunder diperoleh melalui penelitian kepustakaan yang dikomparasikan dan diinterprestasikan dengan data primer yang berupa fakta-fakta hukum yang benar-benar terjadi di lokasi penelitian. Data dalam penelitian ini dianalisis secara kualitatif yang artinya analisis ini hendak mencari kebenaran berdasarkan nilai atau kualitas data yang diperoleh

\section{Analisis dan Pembahasan}

\section{A. Pemenuhan Hak Atas Pendidikan}

Pendidikan adalah hak asasi manusia dan telah memperoleh status sebagai salah satu hak asasi yang bersifat fundamental, khususnya pendidikan dasar. ${ }^{19}$ Hak atas pendidikan tersebut merupakan bagian dari hak ekonomi, sosial, dan budaya, yang pemenuhannya merupakan bagian dari

\footnotetext{
17 Michele Lamont, 2009, How Professors Think, Inside the Curious World of Academic Judgement, Harvard University Press, hlm. 3.

18 Maria SW Sumardjono, 1997, Pembuatan Usulan Penelitian, Gramedia, Jakarta, hlm. 27.

${ }^{19}$ Pasal 26 Deklarasi Universal Hak Asasi Manusia 1948 dan Pasal 13 Kovenan Hak Ekonomi Sosial dan Budaya 1966.
}

195 kewajiban negara kepada rakyatnya. ${ }^{20}$ Pada prinsipnya, setiap orang mempunyai hak yang sama untuk mengikuti pendidikan dan menikmati hasil-hasilnya pada semua tingkatan pendidikan tanpa diskriminasi. 21 Pemerintah harus meletakkan pendidikan sebagai hak dan menyebarluaskan pemahaman akan hal itu (diseminasi), memonitoring dan mengevaluasi atas pelaksanaannya (monitoring dan evaluasi), dan melaksanakan kebijakan-kebijakan berdasarkan dua langkah terdahulu tersebut secara nyata (adjudikasi). ${ }^{22}$

Robert McCorquodale menguatkan asumsi yuridis bahwa hak atas pendidikan dalam sistem hukum internasional memiliki sifat dasar yang memaksa. Argumen ini didasarkan pada keyakinan hukum bahwa subyek-subyek hukum internasional, khususnya organisasi internasional secara konsisten menempatkan kewajiban pemenuhannya secara imperatif bagi anggotanya. Organisasi internasional memiliki kewajiban internasional

\footnotetext{
${ }^{20}$ Yosep Adi Prasetyo, 2012, "Hak Ekosob dan Kewajiban Negara", Pemerkuatan Hak Asasi Manusia Untuk Hakim Seluruh Indonesia, Holiday Resort Lombok, 28-31 Mei 2012, hlm. 2-6 dan Charles Beitz, 2009, The Idea of Human Rights, Oxford University Press, hlm. 7-8.

${ }^{21}$ Pasal 3 Undang-Undang Nomor 20 tahun 2003 tentang Sistem Pendidikan Nasional.

${ }^{22}$ Keppres Nomor 40 Tahun 2004 Tentang Rencana Nasional HAM RI dan Peraturan Presiden Nomor 23 tahun 2011 Tentang Aksi Nasional HAM tahun 2010-2015 dan Perpres Nomor 75 Tahun 2015 tentang Rencana Aksi Nasional HAM Republik Indonesia.
} 
terhadap perlindungan HAM, khususnya pemenuhan hak atas pendidikan berdasarkan 3 (tiga) argumen hukum, yaitu: (1). Organisasi internasional tidak boleh bertindak bertentangan dengan kewajiban hukum yang dimiliki oleh anggotanya terhadap kewajiban mereka pada instrumen perlindungan hukum HAM yang diterimanya, khususnya pemenuhan hak atas pendidikan; (2). Organisasi internasional terikat pada hukum kebiasaan internasional mengenai perlindungan HAM sama seperti pada negara dan individu dalam memenuhi hak atas pendidikan yang telah menjadi tujuan utama dari pendiriannya; dan (3). Kewajiban hukum perlindungan HAM tersebut telah berkembang ke organisasi internasional secara langsung. ${ }^{23}$ Sebagai contoh mutakhir mengenai status hak atas pendidikan dalam sistem hukum internasional, Deklarasi HAM ASEAN mengambil ketiga argumen hukum ini sebagai rasionalitas dan fakta hukum pembentukan norma dan mekanisme pembentukan hak atas pembangunan. ${ }^{24}$ Dalam perkembangan terkini, hak

\footnotetext{
${ }^{23}$ Robert McCorquodale, 2009, International Organizations and International Human Rights Law: One Giant Leap for Humankind, dalam Kaiyan Homi Kaikobad and Michael Bohlander, 2009, International and Power Perspective on Legal Order and Justice, Martinus Nijhoff Publishers, hlm. 154-156.

24 Heppy Ratna, AICHR dan Penguatan Perlindungan HAM di ASEAN, http://news.antara.co.id/berita/1256362459/aich r-dan-penguatan-perlindungan-ham-di-asean, 2019.
}

atas pendidikan merupakan salah satu hak asasi dasar yang memungkinkan setiap manusia bisa berperan aktif dalam pembangunan. Dalam Preamble of the Declaration on the Right to Development, ${ }^{25}$ asas-asas dasar yaitu partisipasi dan non diskriminasi menjadi dasar utama dalam pengembangan pendidikan seseorang berdasarkan kesamaan. Kesamaan tersebut tercermin dalam hal Negara berperan dan wajib menyediakan pendidikan bagi semua orang, menjamin bahwa setiap orang memiliki akses terhadap pendidikan tanpa ada diskriminasi, 26 serta berkewajiban menghilangkan hambatan-hambatan dalam akses memperoleh pendidikan baik dalam bidang legislatif dan dalam bidang lainnya. ${ }^{27}$ Transformasi efektif nilai-nilai HAM dibidang pendidikan harus didasarkan pada asas ketersediaan (availibility), kesempatan memperoleh (accessability), asas penerimaan (acceptability) dan asas penyesuaian (adaptability) berdasarkan kondisi negara, lingkungan sosial dan interaksi kultural senyatanya, sehingga aplikasi

\footnotetext{
${ }^{25}$ General Assembly Resolution $41 / 128$ of 4 December 1986, see $<$ http://www.unhchr.ch/html.menu3/b/74.htm>, United Nations, Human Rights: A Compilation of International Instruments (1993, Vol. I second Part), hlm. 544-549.

${ }^{26}$ Geraldine Van Bueren, 1998, International Documents on Children, Martinus Nljhoff Publisher, hlm. 317-322.

${ }^{27}$ Manfred Nowak, "The Right to Education" dalam Asbjorn Eide, et al, 1995, Economic, Social and Cultural Rights, A Textbook, hlm. 196.
} 
dari penerapan nilai-nilai tersebut dalam pendidikan justru menjadi hak asasi manusia yang fundamental yang eksistensinya tidak dapat dikurangi dalam keadaan apapun (non derogable right).

\section{Pemerataan}

pendidikan

merupakan isu paling kritis karena berkait erat dengan isu sensitif, yakni keadilan dalam memperoleh akses pendidikan. ${ }^{28}$ Memperoleh pendidikan yang layak merupakan hak asasi setiap warga bangsa yang dijamin Konstitusi. ${ }^{29}$ Maka, pemerintah wajib memberi pelayanan pendidikan yang baik kepada seluruh masyarakat. Pendidikan menurut Pasal 1 angka 1 UU Nomor 20 Tahun 2003 tentang Sistem Pendidikan Nasional adalah usaha sadar dan terencana untuk mewujudkan suasana belajar dan proses pembelajaran agar peserta didik secara aktif mengembangkan potensi dirinya untuk memiliki kekuatan spiritual keagamaan, pengendalian diri, kepribadian, kecerdasan, akhlak mulia, serta keterampilan yang diperlukan dirinya, masyarakat, bangsa dan negara. Dengan demikian, pendidikan dapat diartikan baik sebagai proses maupun

\footnotetext{
${ }^{28}$ Ifdal Kasim dan Johanes Masenus Arus, 2001, Hak Ekonomi, Sosial dan Budaya", Esai-Esai Pilihan, Elsam, hlm. xiii.

${ }^{29}$ Putusan Mahkamah Konstitusi dalam Perkara Nomor 012/PUU-III/2005 Mengenai Pengujian Undang-Undang Nomor 36 Tahun 2004 Tentang Anggaran Pendapatan Belanja Negara.

197
}

sebagai tahap khusus dalam proses tersebut. ${ }^{30}$

Pada mulanya, pendidikan merupakan tanggung jawab masyarakat dan penduduk sebagai bentuk pemindahan keterampilan-keterampilan teknis yang diperlukan untuk menjalankan tugas dalam kehidupan sehari-hari, pemindahan nilai-nilai agama, filosofi, sosial dan budaya dari masyarakat dan penduduk tersebut kepada generasi yang lebih muda. ${ }^{31}$ Baru setelah munculnya negara modern, pendidikan dianggap merupakan sebuah masalah publik yang pemenuhannya merupakan kewajiban negara. Pandangan bahwa pendidikan merupakan kewajiban negara disepakati baik oleh konsep liberal HAM maupun konsep sosialisme HAM. ${ }^{32}$ Dalam pandangan konsep liberal HAM, kewajiban negara untuk memenuhi hak pendidikan diletakkan berdampingan dengan kewajiban yang dimiliki oleh orang tua dalam memberikan pendidikan bagi anak-anak mereka. ${ }^{33}$ Kewajiban negara dalam hal ini adalah lebih pada aspek menjamin bahwa setiap anak menerima pendidikan yang cukup

\footnotetext{
${ }^{30}$ Kasim, op.cit., no. 55, hlm. 214.

${ }^{31}$ Gatut Saksono, 2008, Pendidikan yang Memerdekakan Siswa, Rumah Belaajar Yabinkas, hlm. 17-20.

32 lbid., hlm. 25-30.

33Yuli Fajar Susetyo, 2010, "Pendidikan Humanis", Modul Pembelajaran Penataran Hak Asasi Manusia Bidang Pendidikan Se-Provinsi kalimantan Barat, Biro Hukum Hukum dan Organisasi Setjen Kemdikbud-UGM, hlm. 89-91.
} 
melalui pengaturan formal terhadap kurikulum sekolah-sekolah.

John Stuart Mill melukiskan hubungan antara kewajiban negara dan kewajiban orang tua dalam pendidikan tersebut sebagai berikut: "Jika pemerintah gigih menuntut hak pendidikan yang baik bagi setiap anak, maka pemerintah dapat mengusahakan sendiri suatu pendidikan yang baik. Pemerintah dapat menyerahkan kepada para orang tua kemungkinan untuk memperoleh pendidikan di mana dan sebagaimana mereka sukai dan merasa puas dengan membantu membayar uang sekolah anak-anak dari golongan yang lebih miskin dan membiayai seluruh biaya sekolah mereka". ${ }^{34}$ Pandangan sosialisme menekankan bahwa pemenuhan hak atas pendidikan merupakan salah satu tugas utama negara. ${ }^{35}$ Pengaruh yang cukup besar dari ideologi sosialisme terhadap pemikiran founding fathers Indonesia menyebabkan pandangan inilah yang diterima dan dirumuskan sebagai salah satu tujuan negara Indonesia sebagaimana termuat dalam Pembukaan UUD $1945 .^{36}$

Sebagai salah satu jenis hak generasi kedua HAM, hak atas pendidikan tidak terlepas dari ciri-ciri

\footnotetext{
${ }^{34}$ Peter Baehr, Pieter Van Dijk, Adnan B. Nasution, Leo Zwaak, 2001, Instrumen Internasional Pokok Hak-hak Asasi Manusia, Yayasan Obor Indonesia, Jakarta, hlm. 102.

${ }^{35}$ Kasim, loc.cit., no. 55, hlm. 218.

${ }^{36}$ Saksono, loc. cit.
}

yang melekat pada hak ekonomi sosial dan budaya. Secara klasik, generasi kedua dikenali dengan ciri-ciri sebagai berikut, ${ }^{37}$ yaitu: (a). Mencapai atau meraihnya dilakukan secara bertahap; (b). Campur tangan atau keaktifan negara sangat dituntut dalam pelaksanaannya; (c). Pelanggaran terhadapnya tidak bisa diajukan ke pengadilan; (d). Ketergantungan pada sumber daya yang ada; dan (d). Bersifat ideologis. Meskipun kesahihan dari ciri-ciri klasik sulit untuk dipertahankan, namun secara umum pelaksanaan hak-hak generasi kedua HAM memang tidak terlepas dari hal tersebut.

Pasal 13 dan 14 ICESCR telah menetapkan kewajiban-kewajiban internasional yang mengikat setiap negara yang meratifikasi kovenan ini pada intinya adalah kewajiban untuk memberikan pendidikan pada setiap orang dan pemenuhan pendidikan dalam setiap jenjang dengan kemudahan pada obyek pendidikan seperti penyelenggaraan pendidikan dasar yang wajib dan cuma-cuma, pengembangan pendidikan lanjutan dan pelaksanaan komitmen melaksanakan pendidikan fundamental. ${ }^{38}$ Kegagalan negara dalam melaksanakan salah satu kewajiban tersebut di atas merupakan pelanggaran terhadap hak-hak tersebut. Selain terkena pelanggaran karena tidak

\footnotetext{
${ }^{37}$ Ibid., hlm. 62.

${ }^{38}$ Heribertus, op.cit., no. 12, hlm. 17.
} 
menghormati hak tersebut, negara juga dapat dikatakan telah melakukan pelanggaran karena tidak melakukan perlindungan, di mana negara berkewajiban untuk mencegah pelanggaran hak atas pendidikan. Bahkan seringkali, negara bukan saja melakukan pembiaran terhadap tindakan-tindakan pelanggaran namun justru negara sendiri yang menjadi pelaku pelanggaran tersebut. ${ }^{39}$

\section{B. Pemenuhan Hak Atas Pendidikan Dasar di Kota Singkawang}

Khusus

mengenai

pelaksanaan pendidikan dasar di Kota Singkawang, pemaparan dilakukan dengan menggunakan indikator-indikator yang dikemukakan oleh Katarina Tomasevsky, yaitu: ketersediaan (availability), dapat diakses (accessibility), dapat diterima (acceptability) dan kesesuaian (adaptibility). Pemaparan data yang pertama adalah mengenai ketersediaan (availability) yang menuntut sarana dan prasarana pendidikan dasar. Karena pendidikan yang diwajibkan di Indonesia adalah wajib belajar 9 tahun, maka konsep pendidikan dasar ini mencakup bagi semua anak usia Sekolah Dasar dan Sekolah Menengah Pertama di Kota Singkawang. Dimulai dari keadaan gedung sekolah dan fasilitas penunjang lainnya.
Jumlah gedung sekolah di tingkat pendidikan dasar di Kota Singkawang pada tahun 2019 adalah sebanyak 128 sekolah, yang terdiri dari 95 SD dan 33 SMP swasta yang tersebar di seluruh kecamatan di Kota Singkawang. Selengkapnya mengenai jumlah gedung SD di masing-masing Kabupaten/Kota dapat dilihat dalam grafik di bawah ini:

\section{Grafik 1}

\section{Jumlah SD dan SMP per Kecamatan di Kota Singkawang (2019)}

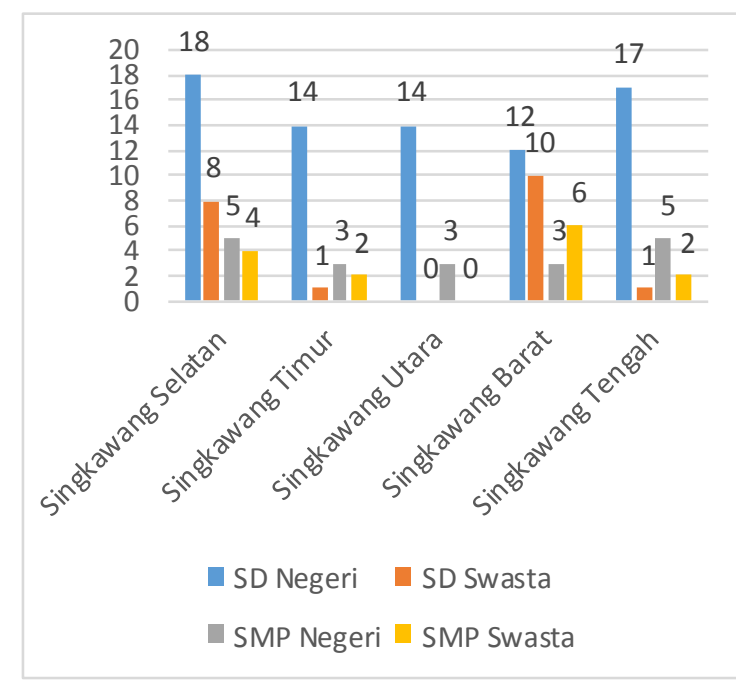

Sedangkan jumlah murid untuk SD dan SMP di Kota Singkawang dari tahun 2017 hingga tahun 2019 secara rata-rata berjumlah 27 ribu orang untuk jenjang pendidikan SD dan 12 ribu orang untuk jenjang pendidikan SMP. 
Grafik 2

\section{Jumlah Murid SD dan SMP di Kota \\ Singkawang (2017-2019)}

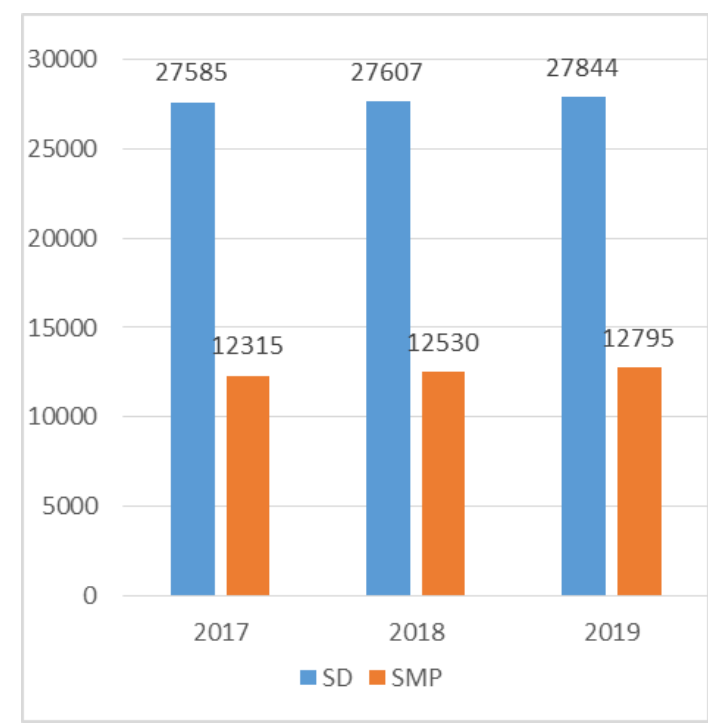

Dari data yang ditampilkan dalam grafik 3 dan 4 terlihat bahwa rata-rata setiap SD rata-rata bisa menampung jumlah siswa sekitar 280-290 orang murid sedangkan untuk SMP secara rata-rata dapat menampung jumlah siswa sekitar 365-395 orang murid. Dari jumlah ini dapat dikatakan bahwa secara aspek ketersediaan (availability) hak atas pendidikan dasar di Kota Singkawang sudah terpenuhi karena meskipun tidak terlihat adanya peningkatan (progress), namun dari angka tersebut dapat dilihat bahwa ada keberlanjutan (sustainability) yang stabil dan yang lebih penting bahwa ketersediaan sekolah baik SD dan SMP di Kota Singkawang memang masih cukup ideal untuk menampung seluruh murid yang ada.

Aspek yang kedua adalah dapat diakses (accessibility). Untuk mengukur aspek ini salah satu indikator penting adalah melihat apakah penduduk Kota Singkawang pada usia sekolah tertentu dapat menikmati fasilitas pendidikan di sekolah-sekolah yang tersedia. Untuk itu dapat dilihat pada Angka Partisipasi Murni (APM) dan Angka Partisipasi Kasar (APK) baik untuk jenjang pendidikan SD maupun SMP selama 3 tahun terakhir.

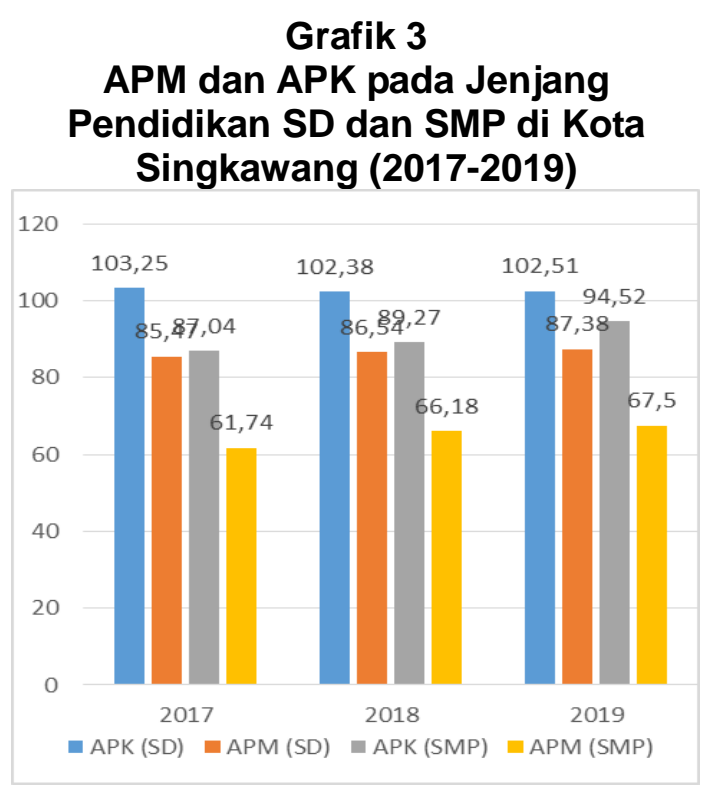

Dilihat dari APK yang berarti adalah merupakan persentase jumlah penduduk yang sedang bersekolah pada suatu jenjang pendidikan (berapapun usianya) terhadap jumlah penduduk usia sekolah yang sesuai dengan jenjang pendidikan tersebut, maka pada tingkat pendidikan SD dapat terlihat bahwa semua anak usia SD (7-12 tahun) di Kota Singkawang telah berada di SD-SD yang ada di Kota Singkawang atau dengan kata lain anak-anak usia SD tersebut telah bisa mengakses sarana pendidikan yang tersedia. Bahkan APK tersebut 
menunjukkan bahwa ada anak-anak di luar usia 7-12 tahun yang sedang menikmati atau mengakes sarana pendidikan yang tersedia. Sementara dari ukuran APM bisa terlihat persentase jumlah anak pada kelompok usia sekolah tertentu yang sedang bersekolah pada jenjang pendidikan yang sesuai dengan usianya terhadap jumlah seluruh anak pada kelompok usia sekolah yang bersangkutan. Dengan demikian APM dapat mengukur proporsi anak yang bersekolah tepat waktu.

Sementara pada jenjang pendidikan SMP terlihat data bahwa belum semua anak pada usia pendidikan SMP (13-15 tahun) menikmati sarana pendidikan yang tersedia. Hal tersebut terlihat baik dalam APK maupun APM yang belum menunjukkan angka mencapai 100\%. Dengan demikian belum semua anak-anak pada usia pendidikan tersebut dapat mengakes sarana pendidikan yang tersedia.

Aspek berikutnya adalah keberterimaan (acceptability). Untuk mengukur aspek ini salah satu indikator yang paling berpengaruh adalah bagaimana jumlah atau rasio murid terhadap guru. Berdasarkan data bahwa rasio guru terhadap murid di tingkat SD relatif stabil meskipun terlihat bahwa peningkatan jumlah murid dari tahun 2017 hingga tahun 2019 hanya diikuti oleh penambahan jumlah guru pada tahun 2018, tetapi jumlah ii berkurang lagi pada tahun 2019. Namun secara rata-rata rasio murid terhadap guru pada tingkat SD masih memenuhi standar. Pada tingkat SMP kenaikan jumlah murid diimbangi dengan penambahan jumlah guru yang sangat signifikan pada tahun 2018 sehingga rasio murid terhadap guru juga berubah secara siginfikan. Berkurangnya jumlah guru pada tahun 2019 dibanding tahun 2018 ttidak banyak mengubah rasio yang ada.

Tabel 1

Jumlah Guru dan Murid Serta Ratio di SD dan SMP di Kota Singkawang (2017-2019)

\begin{tabular}{|c|c|r|r|r|}
\hline Tahun & Jenjang & Murid & Guru & Rasio \\
\hline 2017 & SD & 27.585 & 1.338 & 20,62 \\
\hline \multirow{2}{*}{2018} & SMP & 12.315 & 602 & 20,46 \\
\hline \multirow{2}{*}{2019} & SD & 27.607 & 1.364 & 20,24 \\
\cline { 2 - 5 } & SMP & 12.530 & 782 & 16,03 \\
\hline & SD & 27.844 & 1.296 & 21,48 \\
\hline & SMP & 12.795 & 754 & 16,97 \\
\hline
\end{tabular}

Berdasarkan data dalam tabel di atas dapat disimpulkan bahwa dari aspek keberterimaan (acceptability), pemenuhan hak atas pendidikan dasar di Kota Singkawang sudah terlaksana.

Aspek terakhir yang menjadi indikator dalam pemenuhan hak atas pendidikan adalah kesesuaian (adaptibility). Aspek ini menuntut negara untuk menjamin bahwa sistem pendidikan yang diterapkan di sekolah-sekolah sesuai dengan tahap-tahap perkembangan anak memang agak sulit karena berkaitan 
dengan kebijakan kurikulum sekolah. Pada jenjang pendidikan dasar, kurikulum harus menekankan pada muatan kecakapan dasar (basic learning contents) yang mencakup kecakapan berkomunikasi (membaca, menulis, mendengarkan dan menyampaikan pendapat), kecakapan intrapersonal (pemahaman diri, penguasaan diri, evaluasi diri, tanggung jawab dan sebagainya), kecakapan interpersonal (bersosialisasi, bekerjasama, mempengaruhi/mengarahkan orang lain, bernegosiasi dan sebagainya) dan kemampuan untuk mengambil keputusan (memahami masalah, merencanakan, analisis, menyelesaikan masalah dan sebagainya).

Berbicara mengenai kurikulum yang ada di sekolah-sekolah tidak dapat dilepaskan pada pengambilan keputusan di level nasional, meskipun pendidikan pada tingkat SD dan SMP menjadi kewenangan daerah menurut UU No. 23 Tahun 2014 tentang Pemerintahan Daerah. Justru yang agak mengkhawatirkan mengenai kurikulum adalah begitu mudahnya kurikulum berubah, sehingga belum sempat kurikulum yang satu dinilai berhasil atau tidak, sudah muncul kurikulum baru yang menggantikannya.

Kurikulum yang saat ini berlaku di tingkat SD dan SMP adalah Kurikulum Tahun 2013 (K-13) yang menggantikan Kurikulum Tahun 2006 yang lebih dikenal dengan Kurikulum Tingkat Satuan Pendidikan (KTSP). KTSP sendiri berjalan kurang lebih 6 tahun. KTSP dikenal dengan sifatnya yang desentralistik dalam arti bahwa daerah maupun sekolah diberikan kebebasan untuk mengembangkan dan memutuskan kurikulum sepanjang sesuai dengan Standar Nasional Pendidikan yang ditetapkan oleh Badan Standar Nasional Pendidikan, yang terdiri dari Standar Isi (SI) dan Standar Kompetensi Lulusan (SKL) untuk pendidikan dasar dan menengah.

Pada tahun 2013, K-13 ditetapkan dan diberlakukan namun secara terbatas atau secara uji coba di beberapa sekolah yang ditetapkan sebagai sekolah rintisan. Itupun mulanya hanya diberlakukan untuk kelas I dan IV pada jenjang SD serta kelas VII untuk SMP di samping juga untuk kelas $X$ untuk SMA/SMK. K-13 memiliki empat aspek penilaian yaitu aspek pengetahuan, aspek keterampilan, aspek sikap dan aspek perilaku. Pada tanggal 11 Desember 2014, melalui Peraturan Mendikbud No. 60 Tahun 2014, Menteri Pendidikan dan Kebudayaan pada saat itu memutuskan untuk menghentikan K-13 dan meminta sekolah-sekolah untuk kembali menggunakan KTSP, sementara K-13 sendiri sudah berjalan hampir 6 bulan dan buku-buku penunjang K-13 sudah didistribusikan ke seluruh sekolah-sekolah di Indonesia. 
Pada akhirnya memang K-13 diberlakukan kembali hingga saat ini, namun permasalahan di dunia pendidikan yang sering berganti kurikulum pada dasarnya kerapkali membuat guru dan juga murid kesulitan karena harus segera beradaptasi.

Di samping keempat aspek tersebut di atas, komitmen untuk memajukan pelaksanaan pendidikan, termasuk pendidikan dasar, juga dapat dinilai dari besaran anggaran belanja yang dialokasikan untuk sektor pendidikan. Mengenai besaran anggaran belanja yang dialokasikan untuk sektor pendidikan khususnya pendidikan SD dan SMP di Kota Singkawang dari tahun 2017-2019 dapat dilihat dalam tabel di bawah ini:

Tabel 2 Jumlah Anggaran Pendidikan Bagi SD dan SMP di Kota Singkawang (2017-2019)

\begin{tabular}{|c|c|}
\hline Tahun & $\begin{array}{c}\text { Jumlah Anggaran SD \& } \\
\text { SMP }\end{array}$ \\
\hline 2017 & 48.215 .810 .035 \\
\hline 2018 & 55.973 .673 .074 \\
\hline 2019 & 47.445 .694 .875 \\
\hline
\end{tabular}

Besaran angka dari anggaran pendidikan bagi SD dan SMP di Kota Singkawang terlihat sangat fluktuatif. Tidak ada penjelasan mengapa anggaran pendidikan SD dan SMP di tahun 2018 meningkat dibanding tahun 2017, meskipun dari data salah satu yang terlihat adalah bertambahnya jumlah guru dan juga murid di tahun
2018 dibanding tahun 2017. Namn hal ini tidak menjawab kenyataan bahwa anggaran pendidikan tersebut menurun sejumlah kurang lebih 7,5 milyar rupiah di tahun 2019. Dalam kerangka ICESCR maupun penjelasan umumnya terkait dengan pemenuhan hak atas pendidikan selalu menekankan kepada adanya peningkatan secara bertahap termasuk juga sebenarnya menuntut hal tersebut pada anggaran akan pendidikan.

Berbicara anggaran adalah berbicara hal penting termasuk dalam pelaksanaan hak atas pendidikan. Karena dengan anggaran yang mencukupi dapat dipastikan bahwa pemenuhan hak atas pendidikan juga dapat terpenuhi. Sejauh penelusuran peneliti, belum ada dampak atau masalah terkait dengan berkurangnya anggaran untuk pendidikan SD dan SMP pada tahun 2019 tersebut dengan semakin berkurangnya fasilitas, sarana dan prasarana penunjang pendidikan khususnya di jenjang SD dan SMP di Kota Singkawang.

Menakar dan menguji berbagai indikator pemenuhan hak atas pendidikan yang berbasis pada ICESCR, dapat dikatakan bahwa pemenuhan hak atas pendidikan dasar di Kota Singkawang telah sesuai dengan ketentuan internasional yang termuat dalam ICESCR yang telah diratifikasi dan mengikat untuk dilaksanakan oleh negara Indonesia. 


\section{PENUTUP}

Berdsarkan uraian di atas, dapat ditarik kesimpulan penelitian ini bahwa pelaksanaan pemenuhan hak atas pendidikan dasar berdasarkan ICESCR di Kota Singkawang telah secara bertahap dipenuhi. Faktor teknis, faktor geografis dan faktor implementasi ketentuan peraturan perundangan-undangan yang belum sinkron dan komplit menjadi faktor-faktor penentu pemenuhan hak pendidikan dasar di Kota Singkawang. Untuk mengatasi permasalahan-permasalahan yang masih merupakan hambatan dalam pelaksanaan pendidikan dasar di Kota Singkawang, paling tidak ada tiga kebijakan atau program utama sektor pendidikan yang dapat dilakukan, khususnya oleh pemerintah Kota Singkawang, yaitu: 1. pemerataan dan perluasan akses; 2. peningkatan mutu, relevansi dan daya saing; dan 3 . peningkatan governance, akuntabilitas dan pencitraan publik.

Ketiga program ini sekaligus diharapkan dapat mempercepat pemenuhan kewajiban internasional yang diminta oleh Pasal 13 dan 14 ICESCR, khususnya dalam pelaksanaan pendidikan dasar.

\section{Bibliografi}

\section{Buku}

Asbjorn Eide, Catarina Krause, Allan Rosas, 1995, Economic, Social and Cultural Rights, A Textbook,
Martinus Nijhoff, Dordrecht.

Biro Hukum dan Organisasi Setjen Kemendikbud, 2011, "Monitoring dan Evaluasi Pemenuhan Hak Atas Pendidikan di Indonesia Tahun 2011", Kemdikbud.

Bonanza Perwira Taihitu, 2003,
"Penaatan Indonesia Pada
Standar-Standar Hak Asasi
Manusia Internasional", Tesis
Fakultas IImu Sosial dan IImu
Politik Universitas Indonesia.

Charles Beitz, 2009, The Idea of Human

Rights, Oxford University Press.

Colin Wringe, 2006, Moral Education:

Beyond the Teaching Rights and Wrong, Springer.

Committee on Economic, Social and Cultural Rights General Comment 13, The Right to Education (Art. 13), 08/12/99, E/C.12/1999/10, CESCR, 8 December 1999.

Gatut Saksono, 2008, Pendidikan yang Memerdekakan Siswa, Rumah Belaajar Yabinkas.

Heppy Ratna, AICHR dan Penguatan Perlindungan HAM di ASEAN, http://news.antara.co.id/berita/12 56362459/aichr-dan-penguatanperlindungan-ham-di-asean, diakses tanggal 29 Juli 2019.

Heribertus Jaka Triyana, "Implikasi Hukum Ratifikasi Kovenan Hak Ekonomi Sosial dan Budaya Terhadap Pemenuhan Hak Atas 
Pendidikan di Indonesia", Jurnal Hukum dan HAM, Vol. 4 Nomor 1 (Juni 2006)

Ifdal Kasim dan Johanes Masenus Arus, 2001, Hak Ekonomi, Sosial dan Budaya: Esai-Esai Pilihan, Elsam,

Kaiyan Homi Kaikobad and Michael Bohlander, 2009, Internasional and Power Perspective on Legal Order and Justice, Martinus Nijhoff Publishers.

Klaus Dieter Beiter, 2005, The Protection of the Right to Education by International Law, Martinus Nijhoff Publisher.

Michael Freeman and Philip Veerman, 1992, The Ideologies of Children's Rights. Martinus Nijhoff Publishers.

Maria S.W. Sumardjono, 1997, Pembuatan Usulan Penelitian, Gramedia, Jakarta.

Marzuki, "Permasalahan Pemenuhan Hak Atas Pendidikan di Wilayah Provinsi Kalimantan Barat", Makalah Forum Grup Discussion,
Pemetaan Permasalahan

Pendidikan Di Wilayah Perbatasan Negara, Setjen Kemdikbud, Hotel Park Jakarta, 23-24 November 2011.

Michele Lamont, 2009, How Professors Think, Inside the Curious World of Academic Judgement, Harvard University Press.

Peter Baehr, Pieter Van Dijk, Adnan B. Nasution, Leo Zwaak, 2001, Instrumen Internasional Pokok Hak-hak Asasi Manusia, Yayasan Obor Indonesia, Jakarta.

Yosep Adi Prasetyo, 2012, "Hak Ekosob dan Kewajiban Negara", Pemerkuatan Hak Asasi Manusia Untuk Hakim Seluruh Indonesia, Holiday Resort Lombok, 28-31 Mei 2012.

Yuli Fajar Susetyo, 2010, "Pendidikan Humanis", Modul Pembelajaran Penataran Hak Asasi Manusia Bidang Pendidikan Se-Provinsi Kalimantan Barat, Biro Hukum Hukum dan Organisasi Setjen Kemdikbud-UGM 